Bangl. J. Vet. Med. (2008). 6 (1): 31-36

\title{
EFFECT OF VITAMINS, MINERALS AND PROBIOTICS ON PRODUCTION OF ANTIBODY AND LIVE WEIGHT GAIN FOLLOWING VACCINATION WITH BCRDV IN BROILER BIRDS
}

\author{
P. Monoura ${ }^{1}$, M. Rahman², M. F. R. Khan*², M. B. Rahman² and M. M. Rahman ${ }^{2}$ \\ ${ }^{2}$ Department of Microbiology and Hygiene, Faculty of Veterinary Science, Bangladesh Agricultural University, \\ Mymensingh-2202, Bangladesh \\ Corresponding author's e-mail address: frkhanbau80@yahoo.com
}

\begin{abstract}
The effect of vitamins, minerals and probiotics supplementation to the balanced ration of the broiler chicks on the immune response and growth performance after vaccination with BCRDV was evaluated. For this 50 broiler birds were divided into five equal groups such as A, B, C, D and E, and five types of separate treatments with normal poultry feed were provided to the indivisual experimental groups. All the birds were vaccinated with BCRDV primarily at 3 days of age and boostered at 17 days of age. The birds of group A, B, C and D were supplemented with only probiotics, mixture of probiotics and minerals, mixture of probiotics, minerals and vitamins, respectively. The birds of group E were kept as vaccinated control. Blood samples were collected at the age of $9,12,16,23,26$ and 30 days sequencially. The serum antibody titres were measured by $\mathrm{HI}$ test and ELISA. The highest value of HI antibody titre was $384 \pm 242.65$ (Mean \pm SD) in group B at 23 days of age. The lowest value of $\mathrm{HI}$ at 23 days was $56 \pm 32.86$ (Mean \pm SD) obtained in group C. The ELISA antibody titre was also highest (4675.12 \pm 485.72$)$ at 23 days in group B and obviously the lowest (2169.38 \pm 724.45$)$ in control group E. In case of group C, the ELISA antibody titre was $3105.73 \pm 877.57$ at 23 days but then the titre decreased gradually compared to control group. The highest body weight (1420 \pm 90.82$)$ was recorded at 30 days of age in group D and the lowest value (1188 \pm 44.38$)$ was in group B.
\end{abstract}

Key words: Probiotics, BCRDV, broiler birds

\section{INTRODUCTION}

ND is a deadly viral disease of poultry due to its high contiguousness and rapid spreading in nature among chicken and other domestic and semi-domestic species of birds. ND is being controlled using prophylactic measures such as routine vaccination along with strict hygienic and sanitary condition in the urban area of many developed countries of the world. Vaccination against ND are being practiced from long time as a means of protecting birds from the frequent out break of the disease in various breeds of poultry in Bangladesh. Newcastle disease (ND) is being considered as one of the most important constrains for the development of profitable poultry farming including broiler both in the urban and rural area of Bangladesh.

Optimum age of birds for ND vaccination is influenced by a variety of factors including persistence of maternal antibody in chicks, and delayed development of immune mechanism in chicken. On the other hand, vaccination program may vary with local circumstances such as seasonal variation and prevalence of certain disease (Allan et al., 1978 a,b). As regards vitamin amount vitamin A deficiency in humans and animals greatly increases susceptibility to various infections (Darip et al., 1979). The primary nonspecific host defense in which vitamin A plays an essential role is the resistance of the mucous membranes to microbial colonization, absorption of potentially dangerous antigens, or both.

Present address: ${ }^{1}$ Animal Health and Research Division, Bangladesh Livestock Research Institute, Savar, Dhaka, Bangladesh, 
Feed additives, like antibiotics, hormones and coccidiostats are used in the feed of broiler to improve the efficiency of poultry production. Recently it is believed that probiotics have beneficial effects to improve the productive performance of poultry. The possible mode of action of probiotics includes suppression of viable bacterial count by production of antibacterial compounds such as bacteriocin, competition for nutrients and competition for adhesion sites etc, alteration of microbial metabolism resulting improvement in digestion by increased enzyme activity and the mode of action is by suppression of incompatible enzyme activity and stimulation of immunity by enhanched antibody levels and increased macrophage activity etc (Fuller 1989). In Bangladesh, a variety of probiotics are commercially available in the market and their indiscriminate use without experimental back up is not justified. However according to the information received from the one of the probiotics available in the market of Bangladesh commercially called Protexin ${ }^{\circledR}$ Boost. Vitamin-mineral premix is the combination of vitamins and minerals is added to the formulated diet of broiler to meet up the requirements of at least few vitamins and minerals that are deficient in the commercially available broiler feeds. Deficiency of vitamin and mineral is responsible for various diseases such as xeropthalmia, cage layer fatigue, rickets etc. Like vitamins, the importance of certain trace minerals in immune function has become increasingly evident. Selenium, copper, zinc, cobalt and iron have been found to alter various components of the immune system (Suttle and Jones, 1989). Thus, it is a general practice to add all supplemental vitamins and minerals in a premix at the levels that will provide margins of safety and are adequate under stress conditions to which chickens may be exposed to various infectious agents (Scott et al. 1982). Considering the above factors, the present study was undertaken with a view to evaluating the immune response of broiler chicks against BCRDV when the ration of birds is supplemented by only probiotics; mixture of probiotics and minerals; mixture of vitamins and minerals (vitamin E and selenium), and finally vitamins only and also to compare the effects of vitamins, minerals and probiotics on the level of immunity in broiler following vaccination with BCRDV.

\section{MATERIALS AND METHODS}

The experiment was conducted in the Department of Microbiology and Hygiene, BAU, Mymensingh during the period from July to December 2004.

\section{Immunization}

Fifty day-old broiler chicks with the history of vaccination and ND free parent stocks were purchased from Kazi Farms Ltd., Dhaka. The chicks were divided into 5 equal groups containing 10 birds in each as A, B, C, D and $\mathrm{E}$ followed by vaccination with BCRDV through intraocular (i/o) route at day 3 and boosted at day 17 via intraocular route as per recommendation of the vaccine manufacturer. Beside this the experimental birds also vaccinated with Bur-706 vaccine (Merial, France) at the age of $11^{\text {th }}$ day followed by a booster dose at $21^{\text {st }}$ day intraocularly. The birds were reared by maintaining strict hygienic condition throughout the entire period.

\section{Body weight of birds}

The live body weight of birds of all groups at $0,3,9,12,16,23,26$ and 30 days of age was taken with the help of standard balance on day old age and sequentially at every blood collection and vaccination.

\section{Serology}

Sera samples were obtained from each group following collection of blood at 9, 12, 16, 23, 26, and 30 days of age and were subjected to hemagglutination inhibition (HI) and enzyme linked immunosorbant assay (ELISA) tests to determine the antibody titres.

\section{Analysis of data}

The data were analyzed using computerized statistical program (SPSS) to determine the Mean \pm SD of antibody titre and gained body weight.

\section{Management protocol}

The birds of group A, B, C, and D were fed with Protexin ${ }^{\circledR}$ Boost marketed by Novartis, Bangladesh Limited, a preparation of Probiotics at the level of $2 \mathrm{gm} / 10$ litres of drinking water, mixture of probiotics and minerals $\left(\mathrm{Caldesol}^{\mathbb{B}}\right.$ ) a liquid feed supplement marketed by Speed Care Limited, Dhaka, as formulated by Quality Feeds Ltd., Dhaka., Bangladesh @ 2 ml/iter of drinking water, mixture of vitamins (Eskavit ${ }^{\circledR} \mathrm{E}$ manufactured by Eskayef Bangladesh Ltd. @ 2 gm/10 litre of drinking water) and minerals and only vitamins (Megavit ${ }^{\circledR}$ WS is a water soluble multi-vitamin premix marketed by Novartis (Bangladesh) Ltd. @ 2 gm/10 litre of drinking water, respectively. The birds of group E were kept as vaccinated control, which were fed with normal feed. 
Commercially available poultry feed (Quality Feeds Ltd., Dhaka) was fed throughout the entire period of study. The broiler chicks were fed with standard broiler starter for 14 days and broiler grower for 15-30 days respectively for five days/week. Feed and fresh drinking water with or without probiotics and other feed additives were supplied to the birds of all groups except group E twice in a day.

\section{RESULTS AND DISCUSSION}

The result of immune response and growth performance of birds having vaccinated with BCRDV and the HI and ELISA antibody titres of birds of all groups are presented in Table 1 and 2 respectively.

Table 1 . HI antibody titres ( $\log _{2}$ base) of different groups of birds

\begin{tabular}{|lllllll|}
\hline Vaccination & $\begin{array}{l}\text { Age } \\
\text { (days) }\end{array}$ & \multicolumn{2}{l}{ Antibody titre (Mean \pm SD) } & & \\
\cline { 2 - 7 } & & $\begin{array}{l}\text { Group A } \\
\text { (fed with } \\
\text { only } \\
\text { probiotics) }\end{array}$ & $\begin{array}{l}\text { Group B } \\
\text { (fed with } \\
\text { probiotics } \\
\text { and } \\
\text { minerals) }\end{array}$ & $\begin{array}{l}\text { Group C } \\
\text { (fed with } \\
\text { vitamins } \\
\text { and } \\
\text { minerals) }\end{array}$ & $\begin{array}{l}\text { Group D } \\
\text { (fed with } \\
\text { vitamins) }\end{array}$ & $\begin{array}{l}\text { Group E } \\
\text { (vaccinated } \\
\text { control) }\end{array}$ \\
& & & & & \\
\hline Primary & 9 & $28 \pm 10.954$ & $48 \pm 17.89$ & $30 \pm 28.284$ & $32 \pm 10.954$ & $32 \pm 10.954$ \\
Vaccination & 12 & $20 \pm 12.247$ & $48 \pm 17.89$ & $16 \pm 5.477$ & $32 \pm 29.695$ & $20 \pm 12.247$ \\
Secondary & 16 & $44 \pm 32.863$ & $24 \pm 18.944$ & $22 \pm 10.954$ & $22 \pm 10.954$ & $14 \pm 5.477$ \\
Vaccination & 23 & $64 \pm 21.908$ & $96 \pm 35.777$ & $56 \pm 32.863$ & $68 \pm 55.856$ & $68 \pm 55.856$ \\
& 26 & $96 \pm 35.777$ & $108 \pm 48.166$ & $46 \pm 32.863$ & $88 \pm 43.817$ & $64 \pm 58.991$ \\
& 30 & $224 \pm 87.635$ & $384 \pm 242.652$ & $24 \pm 8.944$ & $92 \pm 65.726$ & $88 \pm 130.076$ \\
\hline
\end{tabular}

$\mathrm{SD}=$ Standard Deviation

Table 2. ELISA antibody titres ( $\log _{10}$ base) of different groups of birds

\begin{tabular}{|c|c|c|c|c|c|c|}
\hline \multirow[t]{2}{*}{ Vaccination } & \multirow{2}{*}{$\begin{array}{l}\text { Age } \\
\text { (days ) }\end{array}$} & \multicolumn{5}{|c|}{ Antibody titre ((Mean \pm SD) } \\
\hline & & $\begin{array}{l}\text { Group A } \\
\text { (fed with } \\
\text { only } \\
\text { probiotics) }\end{array}$ & $\begin{array}{l}\text { Group B } \\
\text { (fed with } \\
\text { probiotics } \\
\text { and } \\
\text { minerals) }\end{array}$ & $\begin{array}{l}\text { Group C } \\
\text { (fed with } \\
\text { vitamins } \\
\text { and } \\
\text { minerals) }\end{array}$ & $\begin{array}{l}\text { Group D } \\
\text { (fed with } \\
\text { vitamins) }\end{array}$ & $\begin{array}{l}\text { Group E } \\
\text { (vaccinated } \\
\text { control) }\end{array}$ \\
\hline \multirow[t]{3}{*}{$\begin{array}{l}\text { Primary } \\
\text { Vaccination }\end{array}$} & 9 & $\begin{array}{l}3073.72 \pm \\
104.4 .57\end{array}$ & $\begin{array}{l}4264.21 \pm \\
730.81\end{array}$ & $\begin{array}{l}2503.42 \pm \\
838.56\end{array}$ & $\begin{array}{l}3423.82 \pm \\
963.14\end{array}$ & $\begin{array}{l}2538.75 \pm \\
595.75\end{array}$ \\
\hline & 12 & $\begin{array}{l}3718.76 \pm \\
795.67\end{array}$ & $\begin{array}{l}4295.78 \pm \\
159.68\end{array}$ & $\begin{array}{l}3218.73 \pm \\
1422.47\end{array}$ & $\begin{array}{l}4063.81 \pm \\
272.81\end{array}$ & $\begin{array}{l}2949.24 \pm \\
620.99\end{array}$ \\
\hline & 16 & $\begin{array}{l}2377.6 \pm \\
211.45\end{array}$ & $\begin{array}{l}3792.14 \pm \\
990.12\end{array}$ & $\begin{array}{l}2549.44 \pm \\
1084.62\end{array}$ & $\begin{array}{l}2810.17 \pm \\
735.03\end{array}$ & $\begin{array}{l}2208.37 \pm \\
258.53\end{array}$ \\
\hline \multirow[t]{3}{*}{$\begin{array}{l}\text { Secondary } \\
\text { Vaccination }\end{array}$} & 23 & $\begin{array}{l}2761.12 \pm \\
499.58\end{array}$ & $\begin{array}{l}4675.12 \pm \\
485.72\end{array}$ & $\begin{array}{l}2055.49 \pm \\
691.04\end{array}$ & $\begin{array}{l}3454.07 \pm \\
835.05\end{array}$ & $\begin{array}{l}2169.38 \pm \\
724.45\end{array}$ \\
\hline & 26 & $\begin{array}{l}3235.96 \pm \\
1003.39\end{array}$ & $\begin{array}{l}3566.70 \pm \\
460.62\end{array}$ & $\begin{array}{l}2490.18 \pm \\
1183.36\end{array}$ & $\begin{array}{l}2677.10 \pm \\
582.85\end{array}$ & $\begin{array}{l}2945.85 \pm \\
778.21\end{array}$ \\
\hline & 30 & $\begin{array}{l}4347.07 \pm \\
117.03\end{array}$ & $\begin{array}{l}2801.30 \pm \\
1026.03\end{array}$ & $\begin{array}{l}3105.73 \pm \\
877.57\end{array}$ & $\begin{array}{l}2674.61 \pm \\
695.35\end{array}$ & $\begin{array}{l}2460.28 \pm \\
314.51\end{array}$ \\
\hline
\end{tabular}

$\mathrm{SD}=$ Standard Deviation 
The mean serum HI antibody titres of broiler chicks of group E vaccinated with BCRDV were $32 \pm 10.954$, $20 \pm 12.247,14 \pm 5.477,68 \pm 55.856,64 \pm 58.991$ and $88 \pm 130.076$, and the ELISA antibody titres were $2538.75 \pm 595.75,2949.24 \pm 620.99,2208.37 \pm 258.53,2169.38 \pm 724.45,2945.85 \pm 778.21$ and $2460.28 \pm 314.51$ at 9 , $12,16,23,26$ and 30 days age of birds respectively. On the other hand the mean serum HI antibody titre of group A receiving BCRDV supplemented with only probiotics were $28 \pm 10.954,20 \pm 12.247,44 \pm 32.863$, $64 \pm 21.908,96 \pm 35.78$, and $224 \pm 87.635$, whereas ELISA antibody titres of this group (A) were 3073.72 \pm 1004.57 , $3718.76 \pm 795.67,2377.63 \pm 211.45,2761.12 \pm 499.58,3235.96 \pm 1003.39$ and $4347.07 \pm 117.03$ at $9,12,16,23,26$ and 30 days aged birds, respectively. The results revealed that the antibody titres were increased in probiotics fed group as compared to the control group E. This is indicated that probiotics had a positive effect on the enhancement of antibody against ND. Such a finding co-related with this of Kabir et al. (2004), Cross (2002) and Shao et al. (2000).

The serum HI antibody titres (Mean \pm SD) of vitamin supplemented group B were 48 $\pm 17.89,48 \pm 17.89$, $24 \pm 18.944,96 \pm 35.777,108 \pm 48.166$, 384 \pm 242.652 whereas the ELISA were $3423.82 \pm 963.14,4063.81 \pm 272.18$, $2810.17 \pm 735.03,3454.07 \pm 835.05,2677.10 \pm 582.85$ and $2674.61 \pm 695.35$ at $9,12,16,23,26$ and 30 days aged birds respectively. The serum antibody titres were higher than that of birds of control group $\mathrm{E}$ which revealed that vitamins had positive effect on the immune response in broiler birds when vaccinated with BCRDV. The results of HI test had a close relationship with the finding of Sklan et al. (1994) who observed that the immune response of chicks were higher when fed with additional vitamin A in their normal ration compared to the additional vitamin A deprived group. Vitamins represents a heterogeneous group of fat-soluble (A, D, E and K) and water-soluble (vitamin B complex, vitamin C) chemical compounds essential in nutrition. All recognized vitamins with the exception of vitamin $\mathrm{C}$ are dietary essentials for poultry. Mineral preparations are important for growth and development of broiler.

The serum HI antibody titres (Mean \pm SD) of group C fed with vitamin and mineral (vit $\mathrm{E}$ and selenium) were $30 \pm 28.284,16 \pm 5.477,22 \pm 10.954,24 \pm 8.944,46 \pm 32.86356 \pm 32.863$ whereas ELISA antibody titres were $2503.42 \pm 838.56,3218.73 \pm 1422.47,2549.44 \pm 1084.62$, 2055.49 $\pm 691.04,2490.18 \pm 1183.36$ and $3105.73 \pm 877.57$ at $9,12,16,23,26$ and 30 days aged birds respectively. These results revealed that vitamin and mineral (vitamin $\mathrm{E}$ and selenium) have limited effects on HI antibody titre but do have positive effect on ELISA antibody titre. The findings related to the result of Swain et al. (2000) who recorded that vitamins and minerals increased cellular and humoral immunity in broiler. The serum HI antibody titres (Mean \pm SD) of broiler chicks fed with mixture of probiotics and minerals ( $\mathrm{Ca}$ and $\mathrm{P}$ ) with the same vaccination schedule of BCRDV were $48 \pm 17.89$, $48 \pm 17.89, \quad 24 \pm 18.944, \quad 384 \pm 242.652, \quad 108 \pm 48.166$ and $96 \pm 35.777$, while the titre of ELISA were $4264.21 \pm 730.81$, 4295.78 $\pm 159.68,3792.14 \pm 990.12$, 4675.12 $\pm 485.72,3566.70 \pm 460.62$ and $2801.30 \pm 1026.03$ at $9,12,16,23,26$ and 30 days aged birds respectively. This indicated that combination of probiotics and minerals had positive effect on the efficacy of BCRDV vaccination in broiler.

Among the five different vaccinated (BCRDV) groups of broiler chick probiotics and minerals fed group (Group B) revealed highest immune response after primary vaccination compared to that of other groups. Following secondary vaccination, the birds of the same group (Group B) again produced the highest HI and ELISA antibody titres than that of other groups. The birds of group A induced the second highest HI and ELISA antibody titres, followed by group $\mathrm{D}$ and the group $\mathrm{E}$ while group $\mathrm{C}$ revealed the lowest immune response.

Higher level of maternally derived antibody (MDA) was found in the birds of all groups. The resultant high levels of MDA found in the progeny chickens are important in protecting the chicken during 10 to 14 days of age from ND. However MDA levels declines gradually and chicks become susceptible to NDV infection which indicated that immunity must be boosted by using vaccine.

\section{Determination of the effect of probiotics, vitamins and minerals on growth performance (weight in grams) of broilers}

The mean live weight gain of birds of group A, B, C, D and E at 0, 3, 9, 12, 16, 23, 26 and 30 days of age are presented in Table 3. The live weights of birds of group A which fed only with probiotics were $53.40 \pm 0.547$, $138 \pm$ 21.679, $296 \pm$ 45.607, $408 \pm$ 39.623, $540 \pm$ 141.833, $758 \pm 42.661,1038 \pm 92.032$ and 1300 \pm 79.056 grams at $0,3,9,12,16,23,26$ and 30 days of age, respectively. Incase of group B having mixture of probiotics and minerals with other ration, the live weight were $53.2 \pm 1.095,172 \pm 22.803,290 \pm 65.192,440 \pm 41.833,548 \pm 59.329$, $738 \pm 64.961,988 \pm 75.630$, and $1188 \pm 44.384$ grams at $0,3,9,12,16,23,26$ and 30 days of age respectively. 
When recorded the live weight of birds, then group C were 53.4 $\pm 1.144,163 \pm 39.937,300 \pm 50,340 \pm 74.161$, $470 \pm 83.666,808 \pm 127.749,1010 \pm 65.192$ and $1370 \pm 120.415$ grams at $0,3,9,12,16,23,26$ and 30 days of age respectively. In case of group $\mathrm{D}$, the measured live weight were $53 \pm 0.707,170 \pm 45.276,316 \pm 42.190$, $420 \pm 57.008,588 \pm 44.384,790 \pm 129.421,1100 \pm 79.056$ and $1420 \pm 90.829$ grams at 0, 3, 9, 12, 16, 23, 26 and 30 days of age respectively. On the other hand live weight of group $E$ the were $53.4 \pm 1.140,126 \pm 43.358$, $250 \pm 35.355,366 \pm 27.018$, 448 $\pm 56.634,708 \pm 109.863$, $1058 \pm 42.661$ and $1280 \pm 75.828$ grams at $0,3,9,12,16$, 23, 26 and 30 days of age respectively.

Table 3. The live weight in grams of birds of different groups supplemented with probiotics, vitamins and minerals

\begin{tabular}{|lllllll|}
\hline Vaccination & $\begin{array}{l}\text { Age } \\
\text { (days) }\end{array}$ & \multicolumn{2}{l}{ Body weight in gm (Mean \pm SD) } & & \\
\cline { 3 - 7 } & & $\begin{array}{l}\text { Group A } \\
\text { (fed with } \\
\text { only } \\
\text { probiotics) }\end{array}$ & $\begin{array}{l}\text { Group B } \\
\text { (fed with } \\
\text { probiotics } \\
\text { and } \\
\text { minerals) }\end{array}$ & $\begin{array}{l}\text { Group C } \\
\text { (fed with } \\
\text { vitamins } \\
\text { and } \\
\text { minerals) }\end{array}$ & $\begin{array}{l}\text { Group D } \\
\text { (fed with } \\
\text { vitamins) }\end{array}$ & $\begin{array}{l}\text { Group E } \\
\text { (vaccinated } \\
\text { control) }\end{array}$ \\
& & & & & \\
Prevaccination & 0 & $53.4 \pm .55$ & $53.2 \pm 1.09$ & $53.4 \pm 1.14$ & $53 \pm .71$ & $53.4 \pm 1.14$ \\
& 3 & $138 \pm 21.68$ & $172 \pm 22.80$ & $163 \pm 39.94$ & $170 \pm 45.28$ & $126 \pm 43.36$ \\
Primary & 9 & $296 \pm 45.61$ & $290 \pm 65.19$ & $300 \pm 50$ & $316 \pm 42.19$ & $250 \pm 35.35$ \\
Vaccination & 12 & $408 \pm 39.62$ & $440 \pm 41.83$ & $340 \pm 74.16$ & $420 \pm 57.01$ & $366 \pm 27.02$ \\
Secondary & 16 & $540 \pm 41.83$ & $548 \pm 59.33$ & $470 \pm 83.67$ & $588 \pm 44.38$ & $448 \pm 56.63$ \\
Vaccination & 23 & $758 \pm 42.66$ & $738 \pm 64.96$ & $808 \pm 127.75$ & $790 \pm 129.42$ & $708 \pm 109.86$ \\
& 26 & $1038 \pm 92.03$ & $988 \pm 75.63$ & $1010 \pm 65.19$ & $1100 \pm 79.06$ & $1058 \pm 42.66$ \\
& 30 & $1300 \pm 79.06$ & $1188 \pm 44.38$ & $1370 \pm 120.42$ & $1420 \pm 90.83$ & $1280 \pm 75.83$ \\
\hline
\end{tabular}

$\mathrm{SD}=$ Standard Deviation

The results of body weight gains support the finding of Kabir et al. (2004) who found that live weight gains were higher in probioties fed group as compared to birds having no probiotics. The results of body weight gains strongly supported the finding of Reza et al. (1983), Sadekuzzaman (2003). In their study these author found that the broiler chicks gained lowest body weight when fed with diet deficient in vitamin mineral premix. The results revealed that probiotics, vitamins and minerals had positive effect on live weight gain in comparison to normal balanced ration. Highest body weight gain was found in the birds of group D (vitamin fed group) compared to other groups. The use of probiotics in the diet has become a phenomenon for maintenance of normal growth and health of birds.

\section{REFERENCES}

1. Allan WH, Lancaster JE and Toth B (1978b). Newcastle disease vaccines, their production and use. Animal Production Series. Chapter 11. Vaccination programmes, pp. 93-102. Food and Agricultural Organization of the United Nations, Rome.

2. Allan WH, Lancaster JE, and Toth B (1978a). Newcastle disease vaccines, their production and use. Animal Production Series. Chapter 3. Selection of the vaccine seed strain, pp. 10-18. Food and Agricultural Organization of the United Nations, Rome.

3. Cross ML (2002). Microbes versus microbes: immune signals generated by probiotic lactobacilli and their role in protection against microbial pathogens. FEMS Immunology and Medical Microbiology 34 (4): 245-253.

4. Darip MDS, Sirisinha and Lamb AJ (1979). Effect of vitamin A deficiency on susceptibility of rats to angiostrongylus contonensis. Proceeding of Society for Experimental Biology and Medicine. 161: 600-604.

5. Fuller R (1989). Probiotics in man and animal. Journal of Applied Bacteriology 66: 365-378. 
6. Kabir SML, Rahman MM, Rahman MB, Rahman MM and Ahmed SU (2004). The Dynamics of Probiotics on Growth Performance and Immune Response in Broilers. International Journal of Poultry Science. 3(5): 361-364.

7. Reza A, Hamid MA and Khatoon A (1983). Effect of using different types of vitamin mineral premix on the performance of broiler chicks. Bangladesh Journal of Animal Science 12: 1-7.

8. Sadekuzzaman M (2003). Effect of vitamin and mineral on the efficacy of BCRDV in chicks. MS thesis, Department of Microbiology and Hygiene, Faculty of Veterinary Science, BAU, Mymensingh.

9. Scott ML, Nesheim MM and Young RJ (1982). Nutrition of chickens. $3^{\text {rd }}$ edn., Scott and Associates, Ithaca, NY, USA. P. 119.

10. Shao L, Zhou L, Li G, Lin F, Shao LP, Zhou LJ, Li GP and Lin FP (2000). Effects of dietary mannan-oligosaccharide and Enterococcus faecium on cell mediated immunity, intestinal microflora and $\mathrm{p}^{\mathrm{H}}$ in chickens. Chinese Journal of Veterinary Science 20 (1): 58-61.

11. Sklan D, Melamed D and Friedman A (1994). The effect of varying levels of dietary vitamin A on immune response in the chick. Poultry Science 73 (6): 843-847.

12. Suttle NF and Jones DG (1989). Recent developments in trace element metabolism and function. Trace elements, disease resistance and immune responsiveness in ruminants. Journal of Nutrition 119: 1055-1061.

13. Swain BK, Johri TS, Swain P and Shrivastav AK (2000). Effect of supplementation of different combinations of some selected nutrients on the performance and immune response of broilers. Indian Journal of Poultry Science 35: 247-251. 